\title{
Jihadism and crime in Spain: a convergence settings approach
}

\author{
Javier Argomaniz, Rut Bermejo
}

\begin{tabular}{|c|c|}
\hline Date of deposit & 15032019 \\
\hline Document version & Author's accepted manuscript \\
\hline Access rights & $\begin{array}{l}\text { (c) } 2019 \text {, The Author(s). This work is made available online in } \\
\text { accordance with the publisher's policies. This is the author } \\
\text { created, accepted version manuscript following peer review and } \\
\text { may differ slightly from the final published version. }\end{array}$ \\
\hline $\begin{array}{l}\text { Citation for } \\
\text { published version }\end{array}$ & $\begin{array}{l}\text { Argomaniz, J., Bermejo, R. (2019). Jihadism and crime in Spain: } \\
\text { a convergence settings approach. European Journal of } \\
\text { Criminology (OnlineFirst). }\end{array}$ \\
\hline $\begin{array}{l}\text { Link to published } \\
\text { version }\end{array}$ & https://doi.org/10.1177/1477370819829653 \\
\hline
\end{tabular}

Full metadata for this item is available in St Andrews Research

Repository at: https://research-repository.st-andrews.ac.uk/

\section{St Andrews Research Repository}




\section{Title: Jihadism and Crime in Spain: A Convergence Settings approach}

\section{Abstract}

This article explores the melting pot of jihadists and criminals that has featured in some of the most significant jihadist attacks and plots foiled in Spain over the last 15 years. Applying Felson's offender convergence settings theory to this case, we argue that the confluence of criminality and jihadism that has been observed in other European contexts has also featured in the Spanish case. Individuals with criminal pasts have utilised their skills for terrorist attacks, a variety of forms of crime have been used to fund terrorism and certain settings such as prisons have facilitated the convergence between criminals and jihadists and enabled a process of identity transition.

\section{Keywords:}

Europe, Terrorism, Petty Crime, Jihadism, Spain

\section{$\underline{\text { Introduction }}$}

Spain is a significant place for jihadism. Not only it figures in their propaganda as a long lost Muslim country that must be re-conquered but it hosts an active community of supporters and sympathisers. The country has also experienced what remains the worst jihadist attack in Europe, the 2004 Madrid train bombings and, more recently, the high-profile 2017 Barcelona attacks. Although, by most accounts, Spain has experienced comparatively less violent radicalisation than other European states over the last decade, it has recently witnessed a spike. Since 2015, Spanish police have arrested more than 200 people for jihadi terrorist crimes -one of the highest numbers in Europe- ${ }^{1}$ and only in 2017 they apprehended 76 suspects of being involved with ISIS-related terrorism. ${ }^{2}$ This represents the highest number of arrests in the last decade. 
This 'new wave of mobilisation, recruitment and jihadist radicalisation', as described by García-Calvo and Reinares (2013), is a response to the establishment of the ISIS 'caliphate' in parts of Syria and Iraq and possesses a number of features that distinguishes it from the previous radicalisation wave that emerged in the shadows of Al Qaeda. It can now be defined as a home-grown phenomenon, extremists are, on average, younger; and online radicalisation is playing a far more important role (Reinares, García-Calvo and Vicente, 2017). A feature, however, that is shared with the previous generation, is the existence of a connection between violent extremism and crime. This linkage constitutes the focus of this study.

As mentioned in the Introduction to this special issue, there have been two phases in the literature on the crime-terror nexus. The traditional understanding remained focused at the organisational level and on how militant and organised criminal groups would engage in different forms of relationship that could be placed in a continuum ranging from sporadic collaboration through stable partnerships to even convergence or hybridisation (Makarenko 2004, Makarenko 2012, Makarenko and Mesquita 2014, Sanderson 2004). The most recent literature concentrates on the analysis of individual and networks, highlighting how criminal and terrorists' profiles, distinct and separate in the past, have now started to merge. In this paper we will argue that the confluence of crime and jihadism observed in the Spanish case does confirm the most recent findings on the subject (Bakker, 2006; Oftedal, 2015; Ranstorp 2016; Neumann, Basra and Brunner, 2016; Clarke 2016). Hence, while Makarenko's CrimeTerror Continuum (2004) described accurately how terrorist and criminal organisations would interact in the past, what we are currently witnessing across Europe is the existence of jihadist grass-root networks (Sageman, 2004) that act differently to the traditional top-down, hierarchical (even bureaucratic) militant organisations -such as ETA or the IRA- that had traditionally characterised terrorism in late $20^{\text {th }}$ century Europe. As Basra and Neumann (2016: 26) contend, 'is not the convergence of criminals and terrorists as organisations but of their social networks, environments, 
or milieus. In other words: rather than being one or the other, criminal and terrorist groups have come to recruit from the same pool of people'. What Basra and Neumann define as the 'New Crime-Terror Nexus' and the editors of this special issue as a 'Melting Pot' of criminals and militants describe a more fluid, unstructured reality that occurs at the micro level of analysis. This new reality challenges past assumptions, including the belief that these two categories of actors would operate under different rationales where militants would seek to destabilise society while criminals would 'merely' want to benefit from the status quo for the sake of financial gain.

The jihadist-criminal shared milieu is not a new development (Bakker already reported in 2006 that about a quarter of the European Islamist terrorists in his study had criminal records) but, with the emergence of ISIS, this trend has been reinforced. More recent figures vary according to the report and country but they are always substantial. For instance, an analysis of 51 successful jihadist terrorist attacks in Europe and North America for the 2014-2017 period found that at least 57 per cent of the attackers had a prior criminal background and one third had been imprisoned before (Vidino, Marone and Entenmann 2017: 58). Stuart (2017: 954) informs us that in the UK, between 1998 and 2015, 38 per cent of IROs [Islamism-related Offences] were committed by individuals with a known criminal history and half of them (19 per cent) had been convicted for non-terrorism related crimes. Indeed, two-thirds of the German foreign fighters had police records prior to travelling to Syria, and one third had criminal convictions, as reported in $2015 .{ }^{3}$ Also in 2015, the French justice ministry spokesman claimed that 15 per cent of the 167 'radical Islamists' detained in France on terror charges had been incarcerated before. ${ }^{4}$

Based on the Spanish case, we will argue that the links between crime and jihadism in the country take a variety of forms that can be articulated through the three elements in the convergence settings theory (functional, financial and ideological confluence) that are outlined in the Introduction to this 
special issue. Although in practice these dynamics tend to blur, we can differentiate them at the analytical level. Felson (2003) coined the term 'offender convergence settings' to describe certain spaces where potential offenders meet each other. For Felson, these were actual physical locations (i.e. a local bar or a restaurant run by organised crime figures) where offenders can meet new people, exchange information and material, buy and sell stolen goods or plan new criminal acts. These places form an 'ecosystem' that cultivates and fosters illegal activities. Following Soudijn and Zegers (2012), our own understanding of 'criminogenic settings' is broader, as it includes the physical (prison, praying rooms, mosques, youth and sport clubs, bars and more) and the virtual places (online forums, social media platforms, dark web) that constitute this shared milieu, the extremist-criminal 'melting pot'.

The existence of these spaces offers 'structure and continuity in the face of individual, group, or network instabilities' (Felson, 2003: 158) as they permit the formation of new contacts, networking, the development of trust and laying the foundations for future collaboration. Yet, most importantly, and this is specific to this particular crime-terror relationship, it allows the shifting of 'careers': the individual's evolution from a (violent) criminal into a (violent) extremist. Gallagher (2016: 53) describes this change as a 'form of progression' from involvement in petty crime from a young age to criminal groups and terrorism. As we will see, this is a process that can be defined by Kruglanski et al's (2009) 'quest for personal significance' theory. And, because the skills required are remarkably similar for both roles, the transition is smoother than it could be initially imagined.

In order to better describe these patterns we will refer to a series of particular cases. We will use these examples to evidence and contextualise the trends we mentioned above. They include well-known individuals such as Abdelbaki Es Satty, the imam who led the cell behind the 2017 Barcelona attack or the criminal network that surrounded Jamal Ahmidan, one of the key plotters of the 2004 Madrid bombings; but we will also be referring to other less-known police investigations that have not been 
explored in depth in the international literature. Data was retrieved from the Spanish Supreme Court and National High Court documents, media reports, academic articles, think tank papers, and face-toface interviews with practitioners from the Spanish police and prison system. These variety of sources allowed us to triangulate the data in order to offer a set of robust findings.

This paper is structured in the following manner: In the main section, the article will discuss in turns the abovementioned confluence dynamics through the analysis of existing evidence. We will then conclude the paper addressing the implications of these findings for the existing literature and the relevance of a convergence settings approach for the study of this subject.

\section{Functional confluence}

With functional confluence we refer to the relationship between criminal skills and militant experience. This is present in a process where criminals become enablers of terrorism by offering their criminal skills (forgery, access to weapons or illegal material, etc.) to an existing cell (Shelley et al. 2005) or a radicalised friend or relative. They are contacted due to their 'talents', religious background or simply the existence of previous personal connections. An alternative is when criminals support the operations of an existing terrorist network with varying degree of integration within the group. Collaboration occurs for different reasons but they are generally pragmatic: criminals are not necessary believers in the cause but they act due to loyalty to friends or members of their social network or simply because they benefit financially or otherwise (i.e. gaining 'street cred' or a reputation in a community).

Evidence from Spain shows how jihadist cells have in the past established contacts with criminals in order to have access to skills and material (explosives, fake passports, etc.) necessary for their 
operations. Such collaboration was essential for the 2004 Madrid attacks that killed 192 people and injured around 2,000 when, on the morning of 11 March 2004, terrorists placed explosives in four commuter trains. The al-Qaeda network behind the attacks obtained the industrial explosive Goma-2 Eco for their rucksack bombs from smugglers who had stolen it from a mine in Asturias (Northern Spain). The group, led by a former miner, José Emilio Suárez Trashorras; smuggled and transported to Madrid the explosives and detonators in exchange of drugs. A key detail is that these contacts were possible due to the fact that Rafá Zouhier, a member of the jihadist cell, and Suárez Trashorras' brother in law became friends during their stay at the Villabona prison in Asturias. After Zouhier introduced Suárez Trashorras to Jamal Ahmidan, a series of meetings in fast food restaurants and over the phone between October 2003 and January 2004 were organised to arrange a deal. ${ }^{5}$

Unlike the above case, we have also witnessed within these overlapping networks criminals who have provided support to cells while being well aware of the potential results of their activities. In these instances they are willing collaborators because they have personal connections, are sympathetic to the cause, or both. Certainly, their technical knowledge, contacts and access to illegal funds can prove very useful. In this way, some of the common criminals who contributed to the Madrid attacks were not particularly religious but they felt compelled through loyalty to the group and friendship and family ties to participate. Reinares has extensively studied what he calls the fourth cluster of individuals within the 2004 Madrid bombings network: This cluster initially consisted of a gang active throughout Spain who specialised in the trafficking of illicit drugs and stolen vehicles. Three of its members, Rachid Aglif, Rafá Zouhier and Otman El Gnaoui, were key figures in the organisation of the attacks, while Jamal Ahmidan was considered the 'linchpin' of this gang 'that morphed into a terrorist outfit in the summer of 2003' (Reinares 2014: 43).

As described in the 11 March attacks sentence, ${ }^{6}$ the criminal and the ideological features of the Madrid network were almost indistinguishable. Aglif was Ahmidan's criminal partner for years, who also 
participated in the meetings with Suárez Trashorras, and they had already planned in 1999 to travel to Chechnya 'to do the jihad'. Aware of Ahmidan's radical ideas, Abdelilah el-Fadual el-Akil, a close associate, helped him to get in contact with Eddin Barakat Yarkas ('Abu Dhadah') during a 2000 trip to the Netherlands. Yarkas was an al-Qaeda member with connections to the 9-11 network who was arrested on 19 November 2001 and charged with fundraising for the terrorist organisation. Furthermore, Jamal Ahmidan's cousin, Hamid, was a fellow co-conspirator and drug trafficker: more than $59 \mathrm{~kg}$. of hashish, 125,000 ecstasy pills, about 19,000 € and fake personal documents were found in his home. In turn, Jamal Zougam, a key member of the network and Ahmidan's criminal associate, hid and transported the explosive devices.

Therefore, evidence from the Madrid attacks shows that there are two different forms of functional confluence. On one hand, the smuggled explosives illustrate how contacts between jihadist and common criminals can be pragmatic and opportunistic and carried out for specific purposes. More a one-off than a lasting partnership. In these circumstances, interaction is kept to a minimum until the transaction is completed or the service carried out in order to avoid the authorities' attention. Arguably, career criminals may not even be fully aware (even if they may suspect it) that they are dealing with terrorists, since they may only know these individuals from their criminal backgrounds. On the other hand, as the examples in the next two sections will amply illustrate, what we observe far more often is how both categories of actors can operate in the same milieu, sharing strong personal connections and, even mutual sympathy for their goals: career criminals may concur with the militants' grievances and support their jihad against the West while the latter approve of the corroding effects of crime in the host society. In the end, this facilitates the establishment of (generally small) terrorist cells hosting criminals-cum-jihadists.

\section{Financial confluence}


In this category we find jihadists who engage in white collar, petty and/or organised crime to fund their operations. Funding sources include Illegal activities such as drugs, firearms and human trafficking, financial crime (banking, VAT, business and social insurance fraud) and organised property crime (Oftedal 2015, Europol 2016, Ranstorp 2016). Proceeds from crime can cover the costs associated with the organisation of terrorist attacks, such as procurement, training, safe houses, travel and more. They can also be diverted to help fund jihadist organisations abroad through money transfer businesses operating, for instance, along the Turkish-Syrian border or by foreign fighters acting as cash couriers (Ranstorp 2016). Here we see low-scale crime as a source of funding for terrorism carried out by either career criminals turned jihadists or militants without a pre-existing criminal background who engage in these actions on an ad hoc and temporary basis.

A facilitating factor is that the sums of money necessary for a terrorist attack are fairly minor: in a study on the financing of jihadi plots in Europe for the period between 1994 and 2013, three quarters of the plots were estimated to cost less than $\$ 10,000$ (Oftedal 2015:3). The Madrid attacks required between 30.000 and 50.000 euros $^{7}$-as estimated by the investigative judge- and these were considerably more sophisticated in execution, and therefore costlier, than the average plot (Oftedal 2015:57). Such 'affordability' allows self-starters to finance without the need of foreign patronage (although a small minority plots have been directly funded by al-Qaeda or ISIS in the past). Selffinancing therefore provides European jihadists with the capacity to operate independently.

An important concomitant issue is that jihadist doctrine enables this process by licensing criminality. Theft is made licit in jihadism through the tenet of 'ghanimah', the wealth 'taken by force from an enemy in times of war' ${ }^{8}$ In this manner, the well-known jihadi cleric Anwar al-Awlaki incited his followers to steal from 'unbelievers' for the sake of 'jihad' (Basra and Neumann 2016: 35). Similarly, high profile jihadist figures in Spain such as Rabei Osman El Sayed Ahmed, known as 'Mohamed the 
Egyptian' and linked to both the $9 / 11$ and the Madrid attacks, had publicly approved of the use of crime to finance jihad. ${ }^{9}$ So crime is, in their eyes, religiously sanctioned, not only permitted but actually endorsed as a religious duty.

If we concentrate further on the Spanish context, evidence of the use of petty crime to finance jihadiinspired violence has surfaced as early as 2004 and 2005 . Originally drug trafficking was the main illegal activity to fund terror but soon we observe the use of other forms of criminality for the same goal. Apart from the above-mentioned example of the Madrid attacks, where explosives were paid for with large quantities of hashish, ${ }^{10}$ drug trafficking has been used to collect money for terrorist plots and support activities in other instances throughout this period. Just a year after Madrid, a June 2005 operation led to the arrest of 11 members of a group connected to the organisation Ansar el Islam, an al-Qaeda affiliate. At the time of the arrest, the group was training and sending suicide bombers to Iraq. Almost everyone in the group was involved in petty crime to sustain their activities: drug trafficking mainly but also document forgery and robbery with violence and physical assault. The amounts obtained through these felonies were transferred to their native countries. ${ }^{11} \mathrm{~A}$ similar strategy was adopted by the Algerian cells dismantled the same year that were moving money to the Salafist group for Preaching and Combat (GSPC). ${ }^{12}$ In this instance, terrorists engaged in robberies, vehicles smuggling, identity document forgery ${ }^{13}$ and credit card fraud in addition to the predictable drug trafficking activities. ${ }^{14}$

Also through credit card fraud, Mohamed Boualem Khouni, an associate of Abu Dhadah and Mohamed Achraf (whom we will return to when discussing radicalisation in prisons), supplied funds and resources to militant groups in Algeria and false documents to individuals travelling to other EU countries. In March 2004, Mohamed Boualem was arrested as part of a police operation and accused of being part of the radical Takfir cell ran by Achraf (Forriol Campos 2013: 191). The group was planning 
to plant a bomb at the Spanish National High Court to target judges and prosecutors working on terrorism cases. ${ }^{15}$

Incidentally, another member of the Achraf cell, Abdelkrim Bensmail, received two money orders totaling $300 €$ from Allekema Lamari, the leader of the Madrid attacks network, while he was in prison serving a sentence for membership of the Armed Islamic Group (AIG). ${ }^{16}$ These are interesting cases because they illustrate how densely connected were the different elements of the jihadist community operating in Spain before the Madrid attacks. More relevantly for this piece, they exemplify how funds could be used in a wide variety of ways to support jihad, including assisting imprisoned fellow terrorists.

With the evolution of the threat, new opportunities have emerged. A new criminal method to fund ISIS was facilitated by the organisation's temporary control of large swathes of Syrian and Iraqi territory. Thus, a support network operating in Valencia were acting as middlemen in the ISIS' plunder and illegal trafficking of the region's cultural and artistic heritage. In parallel they were supplying by sea ISIS and the former Al Nusra Front with explosive material and military uniforms: the police confiscated in February 2016 as many as 20,000 UK army uniforms, including CBRN suits. Using the informal hawala system and money transfers, in three years more than 10 million euros had changed hands (CMVT 2017: 24).

Most recently, it was reported that the Barcelona attacks were financed through the sale of stolen gold and jewels. This was an integral part of the plot since the $1,200 €$ obtained from this method were invested in purchasing the 106 gas canisters that the group was planning to load -together with at least $200 \mathrm{~kg}$ of Triacetone Triperoxide (TATP)- into two rented vans to be used as vehicle-born improvised explosive devices (VBIEDs). ${ }^{17}$ In fact this case is also representative of another important trend: the required amounts were actually rather small; they were squatting on an unoccupied rural 
house that doubled as warehouse and chemical lab, TATP can be produced with cheaply available drugstore products and the vans were obtained from low cost rental businesses. ${ }^{18}$ Another common feature found here is that perfectly legal funds (their own savings, personal property and businesses) were also invested in the plot.

Likewise, as in other European plots, benefit fraud has been used to fund jihadist activities in the country. For instance, Said Lachhab, one of the first foreign fighters to return to Spain, was profiting illegally from social benefits while on a sick leave. A police search found 9,000 euros in $50 €$ notes but not before some funds had been used trying to recruit youngsters to join ISIS in Syria. ${ }^{19}$

Although the criminal methods described so far are rather simple, even mundane, more sophisticated financial crime has also been carried out in support of jihad. In July 2007 two Syrian citizens were arrested in Madrid accused of document forgery, money laundering and collaboration with a terrorist organisation. What is interesting about this particular example is that both men were involved in laundering money from Spanish and foreign jihadists through the Spanish housing market and then remitting the profits outside the country. ${ }^{20}$ In a more recent case from June 2017, a complex businesses structure for tax evasion was set up by a Moroccan man with Danish citizenship and resident in the Spanish enclave of Melilla on the North African coast. Profits were being channeled to an international network of financing, recruitment and travel of foreign fighters to Syria. ${ }^{21}$

This financial confluence highlights the transnational character of the problem. Groups can rely on crime to be able to operate independently but that does not preclude them from having deep European and international connections. Thus, a group of Moroccan jihadist arrested in Barcelona on April 2017 had links to Yassime Attar, the leader of the cell that carried out the attacks at Brussels' airport and metro system the year before. The nine arrested had previous police records, drug trafficking mostly. ${ }^{22}$ In addition, the Achraf group had contacts with other groups in Australia, Belgium, 
the Netherlands and even the United States. ${ }^{23}$ The Ansar Al Islam cell had ties to the Middle East, Maghreb and the United Kingdom ${ }^{24}$ while the GSPC networks dismantled in 2015 were connected to Algerian radical Islamists living in Germany, the Netherlands, UK, Belgium and Denmark. ${ }^{25}$

Taking together, there is clearly significant evidence in Spain of jihadist appropriation of criminal activities. The level of sophistication has varied but generally individuals have engaged in fairly 'ordinary' offences. Yet, even small sums of money collected over time can be effective and dependable sources of funding, especially when the amounts required are not particularly high. On occasion the need for funds required operatives to engage for the first time in these kind of activities but, far more frequently, this was carried out by criminals putting their old skills to a new use. So this is about criminals acting as violent extremists rather than terrorists using the services of specialised criminal actors (i.e. document fraudsters) to help them fund their operations. This distinction is not trivial because it supports Dishman's (2001) argument -albeit made in the traditional Crime-Terror Continuum literature- that militants would in principle prefer to use their 'in-house' capabilities to undertake criminal or political acts in lieu of pursuing collaborative arrangements with criminal groups, as suggested by other scholars.

\section{Ideological confluence}

The existence of settings where jihadists and common criminals converge facilitate the process described in the introduction where criminals 'change career' and integrate within jihadist networks through a process of indoctrination and radicalisation. As reported by Europol (2016: 14), individuals involved in criminal activities and socialised in a criminal environment in Europe are 'amenable to radicalisation processes'. 
Neumann, Basra and Brunner (2016: 3) have described how the jihadist narrative meets the needs of self-doubting criminals seeking a positive identity because it can offer 'redemption'. In other words, joining the global jihad is seen as an opportunity to 'make up for their 'sins" by using their skills and abilities for a political/religious cause. This process can be conceptualised through the notion of 'quest for personal significance' as elaborated by Kruglanski et al. (2009). In a nutshell, feelings of disenfranchisement by second and third generation Muslim youth and the failure to live up to social norms by living a criminal lifestyle can lead to frustration and a personal experience of significance loss. Therefore the decision to join the global jihadist movement can be perceived by the individual, especially at moments of crisis, as a life opportunity to redress this loss and restore one's personal meaning and significance.

Importantly, joining jihad is regarded as an effective way to break with their criminal past without necessarily having always a transformative effect in their day-to-day practices, even if this is accompanied by a profound change in some of their personal views. As we have seen in the financial confluence section, the restoration of a sense of personal significance is facilitated by the fact that following the norms and rules of their adoptive jihadist community allows for the continuation of their criminal activities.

As a matter of fact, jihadism not only serves as a tool for redemption but also as another channel to fulfil the needs and expectations that encouraged them to become involved in crime in the first place: 'jihadist groups offer experiences of power, violence, adventure, and provide them with a strong identity, and - not least - a sense of rebellion and being anti-establishment' (Neumann, Basra and Brunner 2016: 3). French thinker Olivier Roy calls this the 'Islamicisation of radicalism', marginalised young men and petty criminals using Islam as a cover to pursue political violence. ${ }^{26}$ The transition has been assisted by what Gallagher (2016: 54) calls the 'dilution of the requirements and expectations 
for participation in the struggle' where 'the expectation of a solid understanding of the religious cause became secondary'.

Clearly, this is a significant development because, in principle, criminals may make for more effective terrorists, certainly regarding the logistical component of an attack. Even if these individuals are generally only involved at a low level within criminal networks -they do not typically fill major rolesthey benefit from their access to contacts and resources (firearms, financial and transportation means, safehouses). For years they have honed skills in illegal activities that are now useful for violent extremism, including 'staying under the radar'. Furthermore, there is the fact that they have already engaged in unlawful behaviour and, likely, violent crime; which means that they have already crossed an important threshold in the process of radicalisation. Indeed recent research with U.S.-based extremists indicates that those who had engaged in criminal acts before adopting extremist beliefs are 'at an increased risk of engaging in ideologically motivated violence' (Jensen 2018:1). ${ }^{27}$

\section{Convergence settings outside prisons}

Therefore, there is ample evidence that many European jihadists have been brought up and socialised in a criminal environment and that they retain their links to their criminal environment after radicalisation:

While most interactions between individuals involved in criminal activities and terrorist actors are believed to be pragmatic, ad hoc and short-term, others may be sustained and longerterm as these individuals inhabit an intersection of the criminal underworld between radicalised actors and individual criminals, crime groups and networks (Europol 2016: 13). 
Such 'intersection of the criminal underworld', shared spaces or offender convergence settings where the terrorism-criminal 'melting pot' flourishes, can be remarkably varied. While praying rooms and mosques appear frequently in the literature as locations where recruiters can operate, convergence settings may also constitute more trivial places like bars, clubs, fast food outlets and/or restaurants: for example, the Madrid attacks conspirators met in a mobile phones shop owned by Jamal Zougam. ${ }^{28}$

In this regard, it is interesting to note that although private homes and places of worship are the most common radicalisation spaces, as many as 37,5 per cent of those jihadists arrested in Spain between 2004 and 2012 underwent their process of radicalisation and were recruited into terrorism in commercial premises (including hairdressers, clothing and food shops, restaurants or internet and telephone cafés) usually located in the same immediate area (Reinares and García-Calvo 2013: 13). As an illustration, in the Madrid neighbourhood of Lavapiés, a series of local business employing and owned by jihadists and sympathisers served as informal recruitment centres into the jihad in the late 1990s / early 2000s (Reinares 2014).

Convergence does not necessarily occur only in very specific locations but can be typical of whole neighbourhoods or city areas. The relationship between socio-economic deprivation, marginalisation (often concentrated in particular urban spaces) and involvement in jihadist terrorism has already been recognised in other studies looking at the European context (see for instance Ljujic, van Prooijen and Weerman 2017). In the same way than Molenbeek and Schaerbeek in Brussels or the banlieues of Paris are characterised by 'high unemployment, educational disparities, involvement in the prison system' and have been described as a 'breeding ground for terror'29, a well-known convergence setting in Ceuta (a Spanish enclave on North Africa) is the Príncipe Alfonso district. 
Indeed, the Príncipe Alfonso district was portrayed by Jordán and Trujillo (2006: 1) as 'one of the most favourable for the jihadist recruitment in Spain'. Príncipe suffers from

Lack of urbanization, unemployment, illiteracy, delinquency, and other symptoms of social and economic marginalization. For years numerous families living in Príncipe benefitted from the income generated by the trafficking of drugs and human beings. However the constabulary successes in the $90 \mathrm{~s}^{\prime}$ against drug bands and the effectiveness of the measures against illegal immigration decreased remarkably these types of financial income. Consequently the neighbourhood's economic situation has even more deteriorated. (Ibid: 1 )

As described by the authors, this environment of marginalisation and social exclusion normalises transgressive behaviour and a sub-culture of crime and violence where radical preachers and jihadist recruiters can leverage existing close social networks (family, friends, criminal) for their cause.

It was indeed in Príncipe Alfonso where a 11-strong jihadist cell carried out a series of symbolic acts of sabotage and was planning a high-casualty attack before they were detained by the police in 2006 . Many in the group had criminal records justified by claiming that they were obtained in support of jihad (Jordán and Wesley 2007). Likewise, in a separate June 2013 operation that dismantled a 8-man foreign fighter recruitment network, it was found that several of these Príncipe Alfonso residents had been previously involved in drug trafficking. ${ }^{30}$ The group had sent to Syria 50 foreign fighters: 12 from Ceuta and the rest from Morocco. ${ }^{31}$

These findings need to be contextualised: Although Príncipe Alfonso is the best known convergence setting in the literature, anti-terrorist operations have occurred throughout the whole of Ceuta and Melilla in areas that share some of Principe Alfonso features ${ }^{32}$, which would explain the fact that they are two of the country's radicalisation hotspots, only after Madrid and Barcelona in the number of anti-jihadists police operations carried out. Ceuta, a city with a large Muslim population, has itself experienced a rapid increase of radical praying spaces over the last decade. ${ }^{33}$ In similar vein there have 
been other marginalised conflictive areas in mainland Spain where crime-terror melting pots may have emerged: In 2015, for instance, two Moroccan men who were part of an ISIS unit were arrested in La Cañada Real, where one of them was a resident. The infamous Cañada Real is a shanty town in the Madrid region known for being a criminal hub and 'drug supermarket'. ${ }^{34}$

\section{Prisons as 'melting pots'}

A key convergence setting that has received much attention by authorities and experts alike is prisons, regarded as the premier place where criminals and jihadists mix. Basra and Neumann (2016) explained how prisons facilitate the radicalisation of criminals: First, they are places where cognitive openings can occur, leading young, sometimes vulnerable people to re-assess their lives and engage in personal change, which may result in recruitment into the jihad. Moreover, the stigma of prison is a barrier for successful reintegration into society, which in practice can narrow former criminals' life choices into continued involvement in crime and radicalisation.

If we look more closely at the Spanish experience, we can find multiple cases where these (or similar) processes are taking place. In fact, according to the Ministry of Interior, between 2005 and 2011, 20 per cent of those imprisoned for jihadism-related crimes have previously served sentences for other types of crime (De la Corte 2015: 8).

If we turn to specific examples we should include, within the Madrid attacks network, Mohamed Bouharrat, who was sentenced to prison in Spain in 2002, and Jamal Ahmidan, who began its process of radicalisation in 1996 during a period of imprisonment in Morocco (Reinares 2014: 39). The 2006 Ceuta jihadi network was led by Karin Abdelselam Mohamed, a former petty criminal who also became radicalised in prison and formed the group following his release (Jordán and Wesley 2007). He is 
considered to be the first jihadist sentenced for collaborating with ISIS inside Spain. ${ }^{35}$ In another relevant investigation, Lahcen Ikassriem, a former Guantanamo detainee arrested in Madrid in 2014 and convicted for recruiting individuals to fight for ISIS in Syria, claimed during his trial that 'he led his life to Allah thanks to the brothers he met ${ }^{36}$ when he served four years in prison for hashish trafficking.

Another high-profile example of this dynamic that deserves closer attention is the leader of the cell behind the 2017 Barcelona attacks: Abdelbaki Es Satty, who died in an explosion in Alcanar (Tarragona) when manipulating the explosives that the network was planning to use in the attack. Es Satty, an imam in the Catalan town of Ripoll since $2014^{37}$, served two prison sentences: the first was in 2003 when he was charged with human trafficking as he tried to smuggle an immigrant into the country with a forged passport and for which he was sentenced to a six months prison term. A second sentence came in 2010, this time accused of introducing $120 \mathrm{~kg}$ of hashish in Spain, when he served 4 years in the Castellón prison in South-Eastern Spain. During his stay, he met Rachid Aglif, one of the 18 jihadists sentenced for their role in the 11-M attacks, an encounter seen as pivotal in his eventual decision to commit an attack in Spain. ${ }^{38}$

Networks of jihadist recruiters have been very active inside some Spanish jails. In the Segovia prison, Moroccan Abdelmajid Chiakhi was initially sentenced for domestic violence but in November 2015 he was accused of recruiting jihadists among inmates finishing their prison terms ${ }^{39}$. In fact, some particular penitentiaries have acted as specially intense nodes for recruitment, such as Topas (Salamanca). In 2008 Mohamed Achraf was sentenced for his recruiting work in this prison ${ }^{40}$ and this case led to the re-organisation of the FIES (File of Inmates in need of Special Monitoring) a control mechanism set up in 1991 by the Spanish prison system and in place since $1996 .{ }^{41}$ 
Whereas it can be relatively easy to pinpoint the prison experience as the starting point for a process of radicalisation, we should be conscious of the fact that this is not a lineal process. Even if stints in Spanish and Moroccan jails served to strengthen Jamal Ahmidan's support for jihadism; it was not until 2003, outside prison and months after he was released, when he made the step of joining the Madrid attacks cell under the persuasive influence of Serhane Ben Abdelmajid Fakhet ${ }^{42}$, the ideologue of the network with connections to al-Qaeda. ${ }^{43}$ It should not surprise us that this was a process compounded by online radicalisation. Exactly the same pathway followed by two other members of the group, Rachid Aglif and Othman el-Gnaoui, who also served time in prison during the 1990s but, as claimed by Reinares (2014: 57), this had not in fact resulted in the adoption of extremist attitudes. In other words, Ahmidan, Aglif and el-Gnaoui's 'career shift' only took place outside the prison space.

In contrast, it must be noted that the prison experience may not only result in a cognitive opening that leads to recruitment into violent extremism but it can in fact serve to reinforce already ongoing processes of violent radicalisation, sometimes resulting in severe changes in the individual's behaviour. Hence, a perpetrator of the Madrid attacks, the Algerian Allekema Lamari, had been already arrested in 1997 in the Spanish city of Valencia for his GIA membership and sentenced to more than nine years of prison. After serving five years, Lamari left the penitentiary of A Lama (Pontevedra) in June 2002 even more radicalised, according to reports from the Centro Nacional de Inteligencia, the Spanish intelligence agency. ${ }^{44}$

Another revealing (but somewhat less dramatic) example is that of Ismael Boufarcha, a 18 years old webpage administrator arrested in a police operation against a jihadist recruitment cell $^{45}$ and sentenced in 2015 to five and a half years in prison. His Spanish mother has described in the media the religious awakening that his son is going through: "he prays a lot and has a long beard, reads religious books, previously he neither talked about religion nor prayed' ${ }^{46}$ She claimed that his son was 'not a radical' before but he is becoming 'more radical' in jail, using as evidence a picture taken in 
prison of him with a member of the Madrid attacks network. ${ }^{47}$ It must be noted however that this may not be fully representative of current trends: Although it was common in the past to witness changes in physical appearance and individual routines in prison (i.e. requesting halal meal, refusing to eat pork, joining community prayers) this is currently far less prevalent, arguably to avoid detection. ${ }^{48}$

As Trujillo et al. (2009) have indicated, the reinforcement of radicalisation processes amongst Muslim prisoners in Spanish jails is facilitated by well-known behavioral patterns: horizontal cohesion or group identity and conformity (self-identification as a member of a Muslim group), intergroup differentiation (Muslim groups of inmates distancing and separating themselves from the rest of the prisoners), vertical cohesion (in-group hierarchical subordination to Islamist leaders) and, associated with all this, increased legitimisation of terrorism. As mentioned by one of our interviewees, radicals offer new inmates protection and support if they get involved in their gangs. ${ }^{49}$ And these dynamics are stronger in penitentiaries with 'a higher concentration of Muslims and jihadists than in prisons with a lower concentration of the former and absence of the latter' (Ibid 2009: 578).

\section{Conclusion}

It must be acknowledged that an in-depth understanding of personal motivations would have required semi-structured interviews with some of the individuals mentioned in this paper, but we contend that there are still a number of important findings that had emerged from our analysis of the Spanish context. As in other European contexts, there has been an evolution from one form of deviant behaviour to another, a mutated response to situations of alienation and/or marginalisation. In terms of ideological confluence, former criminals experienced a conversion into jihadism as a personal change that provided them with a new sense of purpose: they can now use their past experiences for a 'higher' political cause masquerading as religious duty. Described by recruiters as an opportunity for personal redemption through the greater good, it is a meaning-making exercise, a 'quest for personal significance' as described by Kruglanski et al (2009). 
A salient aspect of this dimension affects those involved in criminal activities who radicalised in prison after being indoctrinated by jihadist leaders. They enter the system as criminals and leave prison as supporters, fellow travellers or, more worryingly, active members of a terrorist network. In this process they embrace a radical and violent interpretation of Islam. The outcomes of the process range from passive belief on a radical creed to the decision to become a foreign fighter abroad (Alonso et al. 2008).

When considering financial confluence, the main conclusion is that jihadists in Spain have engaged from an early stage in a variety of offences to illegally finance their activities: credit card fraud, robbery, identity documents forgery, social benefit fraud and a number of other methods have substituted or complemented drug trafficking, a staple in the criminal-jihadist diet. Often those activities led to no change in the individual practices and/or daily routines, it only meant that some or all amounts obtained through crime would serve a different purpose. Yet, especially with financial crime, we also observe that criminal operations have been put together by terrorist with no previous criminal experience. And even if very often these criminal methods may appear rather banal, in occasions we see that fundraising schemes may also be complex, sophisticated, dealing with very substantial amounts and featuring strong international connections. Finally, financing networks in the 2004-6 period were generally more focused on remitting the funds raised abroad to foreign terrorist organisations but there has been an increase in self-starters that plan to use those resources to act within Spanish territory. Indeed this case study has shown precisely that the confluence of crime and terror that has attracted increased interest following ISIS' emergence does in fact pre-date the appearance of ISIS-affiliated networks in Europe: we already witness these trends in the AI-Qaeda cell that carried out the Madrid attacks almost 15 years ago and in other similar networks operating in Spain during this period. 
Regarding functional confluence, we found participation in jihadist cells by individuals with a criminal past. This substantiates one of the key arguments proposed by the new 'crime-terror' nexus: that within European jihadism the confluence occurs at the individual and not the organisational level. What we would like to emphasise here is that the Spanish case does also demonstrate that social bonds are crucial in the process: kinship, personal relationships and, especially, family ties are not only important to strengthen in-group radicalisation processes but also serve as catalysts for a crimeterrorist confluence. The fact that, oftentimes, this process brings together individuals with similar personal backgrounds needs to be recognised. As does the point that certain neighbourhoods and/or areas within the country suffer from marginalisation and deprivation that facilitates their transformation into melting pots for criminals and violent extremists.

Therefore the notion of 'melting pot' or convergence setting is especially useful to encapsulate processes occurring within the functional and ideological confluence dimensions. Prisons in particular are quintessential offender convergence settings. So we believe this could be a very useful way to approach the issue, as it would be to distinguish between three different forms of confluence. We are certain that a convergence settings approach that distinguishes confluence processes according to functional, financial and ideological dimensions can serve to neatly encapsulate the dynamics that characterise how jihadism and petty crime intermesh currently in Europe.

Yet, although these three patterns can be separated analytically, it must be emphasised that, in practice, they blur. Essentially, the same case can be representative of more than one trend. To illustrate: the Barcelona attacks included perpetrators with criminal records (functional confluence), it was financed through crime (profit confluence) and the leader had spent time in prison, arguably where he radicalised (ideological confluence). As our interviewees took great pains to emphasise, there are individuals who were professional criminals, radicalised in prison, continued with their illegal 
activity to sustain themselves upon release, walked down their path to violent extremism and started planning terrorist acts in the same way they previously prepared criminal ones.

These different forms of confluence highlight the importance of scholars and policymakers' existing work on the reintegration into society of former violent extremists, the practical effectiveness of risk assessment tools and the actual capacity of social work programmes to prevent a transition from crime into political violence. It is clear from the above that the surveillance of violent extremists and terrorist recruiters inside and outside prisons is important but so is a greater understanding of the processes that make terrorist activity attractive to young adults involved in petty crime in our societies.

\section{$\underline{\text { Notes }}$}

\footnotetext{
${ }^{1}$ Un detenido por usar su casa de 'lanzadera' de yihadistas para el ISIS. El País, 6 November 2017. Available at: https://politica.elpais.com/politica/2017/11/06/actualidad/1509950525_477579.html

${ }^{2}$ According to the official data from the Spanish ministry of interior available at: http://www.interior.gob.es/documents/10180/6186126/OPERACIONES+Y+DETENIDOS+YIHADISMO+DESDE+1 $1 \mathrm{M}+\% 2815-02-2018 \% 29 . p d f / 3 c 83 e 3 f 5-81$ ba-4a6b-ad60-8aec382ec751

${ }^{3}$ BKA, BfV \& HKE, 'Analyse der Radikalisierungshintergründe und -verläufe der Personen, die aus islamistischer Motivation aus Deutschland in Richtung Syrien oder Irak ausgereist sind', 2015, p.17 (quoted in Neumann, Basra and Brunner 2016: 7)

${ }^{4}$ Astier, H (2015) Paris attacks: Prisons provide fertile ground for Islamists, BBC, 5 February. Available at: http://www.bbc.co.uk/news/world-europe-31129398

${ }^{5}$ Spanish Supreme Court sentence 503/2008, 17 July 2008.

${ }^{6}$ Spanish Supreme Court sentence 503/2008, 17 July 2008.

${ }^{7}$ El 11-M costó a los terroristas 50.000 euros, $A B C, 23$ November 2007. Available at: http://www.abc.es/hemeroteca/historico-23-11-2007/abc/Nacional/el-11-m-costo-a-los-terroristas-50000euros 1641410719525.html

${ }^{8}$ As explained in: http://www.oxfordislamicstudies.com/article/opr/t125/e709

${ }^{9}$ Interview 3, Spanish police officer, telephone interview, 16 February 2018.

${ }^{10}$ Interview 3, Spanish police officer, telephone interview, 16 February 2018.

${ }^{11}$ Detenidas 16 personas en dos operaciones contra el terrorismo islamista en varios puntos de España. Cinco Días, 15 June 2005. Available at: https://cincodias.elpais.com/cincodias/2005/06/15/economia/1118971406 850215.html
} 
12 La policía detiene a 16 personas que reclutaban a terroristas para enviarlos a Irak. El País, 19 December 2005. Available at: https://elpais.com/elpais/2005/12/19/actualidad/1134983819 850215.html

${ }^{13}$ Alonso dice que los siete detenidos en Málaga enviaban dinero a islamistas en Argelia. El Mundo, 9 December 2005. Available at: http://www.elmundo.es/elmundo/2005/12/09/espana/1134134147.html 14 Interior confirma que los diez detenidos hoy están vinculados a un grupo satélite de Al Qaeda. El País, 23 November 2005. Available at: https://elpais.com/elpais/2005/11/23/actualidad/1132737417 850215.html ${ }^{15}$ Bareño G and Clemente E (2004) Suiza extraditará al jefe de la célula que planeaba «volar» la Audiencia. Diario de León, 21 October. Available at: http://www.diariodeleon.es/noticias/espana/suiza-extraditara-jefecelula-planeaba-volar-audiencia_162434.html

${ }^{16}$ Abdelkrim Bensmail admite que recibió dinero de Lamari, uno de los suicidas de Leganés. El País, 30 October 2007. Available at: http://www.elmundo.es/elmundo/2007/10/30/espana/1193755306.html

${ }_{17}$ Olmo, J. M. (2017) La célula del atentado compró las bombonas con dinero de la venta de oro y joyas. El Confidencial, 21 August. Available at: https://www.elconfidencial.com/espana/cataluna/2017-08-21/atentadobarcelona-y-cambrils-bombonas-de-butano-con-dinero-y-joyas 1431388/

18 Ibid.

${ }^{19}$ Olabarri, D (2017) El yihadista de Vitoria cobraba 1.800 euros al sumar de forma irregular una baja y la RGI, El Correo, 2 March. Available at: http://www.elcorreo.com/bizkaia/sociedad/201702/21/yihadista-vitoriacobraba-euros-20170221180857.html

${ }^{20}$ Detenidos en Madrid dos islamistas sirios que recaudaban dinero para cometer atentados. El País, 25 July 2007. Available at: https://elpais.com/elpais/2007/07/25/actualidad/1185351421 850215.html

${ }^{21}$ Detenido en Melilla un yihadista implicado en una red de envío de combatientes a Siria. El País, 23 June 2017. Available at: https://politica.elpais.com/politica/2017/06/23/actualidad/1498200506 952797.html ${ }^{22}$ Carranco, R (2017) Tres detenidos en Barcelona vinculados a los atentados yihadistas de Bruselas. El País, 25 April. Available at: https://elpais.com/ccaa/2017/04/25/catalunya/1493099200_081105.html

${ }^{23} \mathrm{lbid}$.

${ }^{24}$ See note 22.

${ }^{25}$ Interior confirma que los once detenidos hoy están vinculados a un grupo satélite de Al Qaeda. El País, 23 November 2005. Available at: https://elpais.com/elpais/2005/11/23/actualidad/1132737417 850215.html ${ }^{26}$ Nossiter, A. (2016) 'That Ignoramus': 2 French Scholars of Radical Islam Turn Bitter Rivals. The New York Times, 12 July. Available at: https://www.nytimes.com/2016/07/13/world/europe/france-radicalislam.html?smprod=nytcore-ipad\&smid=nytcore-ipad-share\& $r=1$

${ }^{27}$ According to data from the Profiles of Individual Radicalization in the United States (PIRUS) dataset 'nearly $35 \%$ of the Islamist extremists engaged in criminal acts prior to radicalizing' (2018: 2).

${ }^{28}$ See note 13.

${ }^{29}$ Williams et al (2016) How two Brussels neighborhoods became a 'breeding ground' for terror. The Washington Post, 1 April. Available at: https://www.washingtonpost.com/graphics/world/brusselsmolenbeek-demographics/

${ }^{30}$ Testa, G. (2013) González Pérez: “Quien empieza lanzando piedras llega al 'narco' y acaba viendo ‘la luz de Dios', Ceuta al Día, 24 June. Available at: http://www.ceutaldia.com/articulo/sucesos/gonzalez-perez-quienempieza-lanzando-piedras-llega-narco-y-acaba-viendo-luz-dios/20130624204530131983.html

31 Testa, G (2013) Los presuntos yihadistas del Príncipe mandaron a 12 personas desde Ceuta a Siria a cometer atentados. Ceuta al Día, 22 June. Available at: http://www.ceutaldia.com/articulo/sucesos/presuntos-

yihadistas-principe-mandaron-12-personas-ceuta-siria-cometer-atentados/20130622134532131959.html

32 Interview 1, Ceuta police officer, Madrid, 13 February 2017.

${ }^{33} \mathrm{lbid}$.

${ }^{34}$ Ortega, P (2015) Tres detenidos en Madrid vinculados al terrorismo yihadista. El País, 3 November. Available at: https://politica.elpais.com/politica/2015/11/03/actualidad/1446530674 736867.html

${ }^{35}$ Spanish National High Court sentence 23/2015, 30 September 2015

${ }^{36}$ Spanish National High Court sentence 25/2016, 28 September 2016

${ }^{37}$ El currículum criminal de Es Satty, el cerebro de los atentados del 17-A. ABC, 2 September 2017. Available at: http://www.abc.es/espana/abci-curriculum-criminal-satty-cerebro-atentados-17-a201709020853 noticia.html

${ }^{38}$ El imán de Ripoll trabó amistad en prisión con un terrorista del 11-M. El País, 20 August 2017. Available at: https://politica.elpais.com/politica/2017/08/20/actualidad/1503230607 911490.html

${ }^{39}$ La Policía detiene a un preso por captar yihadistas y amenazar con bombas en Madrid y Barcelona. EI Mundo, 23 November 2015. Available at: http://www.elmundo.es/espana/2015/11/23/56531524ca47415f448b45c8.html 
${ }^{40}$ La cárcel de Topas, epicentro de la radicalización del terrorista Farid Mohamed Al Lal. Tribuna Salamanca, 23 October 2016. Available at: https://www.tribunasalamanca.com/noticias/la-carcel-de-topas-epicentro-de-laradicalizacion-del-terrorista-farid-mohamed-al-lal (access 15 nov 17)

${ }^{41}$ FIES is a regime that classifies inmates according to their individual characteristics, threat degree, and the type of security measures they require. The 3 group categories in this system that relate to radicalisation are: A) Inmates serving terrorism sentences, B) Inmates who are regarded as having leadership and recruitment skills and C) Violent extremists or those already in a process of radicalisation.

In 2014 a novel radicalisation prevention programme was introduced and, more recently, a new compulsory risk/radicalisation assessment tool was put in place in February 2018 (Interview 4, Prison officer, Madrid, 27 February 2018).

${ }^{42}$ Ordaz, P. (2007) "Jamal me dijo desde Leganés que era mejor morirse, que no se iba a entregar", El País, 8 March. Available at:https://elpais.com/diario/2007/03/08/espana/1173308401 850215.html

${ }^{43}$ Rodríguez, J. A. (2005) El doctorado terrorista de El Tunecino. El País, 26 April. Available at: https://elpais.com/diario/2005/04/26/espana/1114466410 850215.html

${ }^{44}$ Rodríguez, J. A. (2004) Lamari, condenado por planear en 1997 ataques con bomba en "medios de transporte". El País, 17 October. Available at:

https://elpais.com/diario/2004/10/17/espana/1097964009 850215.html

${ }^{45}$ Los ocho detenidos por la Policía Nacional formaban una célula de propaganda yihadista conectada con la organización terrorista DAESH. PressRoom Ministerio del Interior, 13 March 2015. Available at: http://www.interior.gob.es/en/prensa/noticias/-/asset publisher/GHU8Ap6ztgsg/content/id/3528948 ${ }^{46}$ García Rey, M. (2017) De la yihad a prisión, de prisión a la yihad. El Confidencial, 10 September. Available at: https://www.elconfidencial.com/espana/2017-09-10/yihadismo-radicalizacion-prisiones-espana 1441155/

${ }^{47}$ Congostrina, A. L. (2015) "Mi hijo es un cabeza de turco". El País, 2 May. Available at: https://elpais.com/ccaa/2015/05/01/catalunya/1430508786 979359.html

48 Interview 2, Prison officer, Madrid, 5 May 2017.

49 Ibid.

\section{$\underline{\text { References }}$}

Alonso, R. et al (2008) Radicalisation Processes Leading to Acts of Terrorism: A Concise Report prepared by the European Commission's Expert Group on Violent Radicalisation. Brussels: Submitted to the European Commission on 15 May 2008.

Bakker E (2006) Jihadi terrorists in Europe: their characteristics and the circumstances in which they joined the jihad - an exploratory study. The Hague: Netherlands Institute of International Relations Clingendael.

Basra R and Neumann P (2016) Criminal Pasts, Terrorist Futures: European Jihadists and the New Crime-Terror Nexus. Perspectives on Terrorism 10(6):25-40.

Centro Memorial de Victimas del Terrorismo (CMVT) (2017) Balance del terrorismo en España 2016. Cuadernos del Centro Memorial de las Víctimas del Terrorismo (3). Vitoria-Gasteiz: CMVT. 
Clarke C (2016) Crime and Terror in Europe: Where the Nexus is Alive and Well. The Hague: ICCT.

De la Corte L (2015) ¿Por qué crecen los vínculos entre Terrorismo y Crimen? Cuadernos de la Guardia Civil. Revista de Seguridad Pública 50: 6-26. Available at: http://bibliotecasgc.bage.es/cgi$\underline{\text { bin/koha/opac-detail.pl?biblionumber }=15545}$

Dishman C (2001) Terrorism, Crime, and Transformation. Studies in Conflict and Terrorism 24(1): 4358.

Europol (2016) Changes in Modus Operandi of Islamic State (IS) revisited. The Hague: Europol.

Felson M (2003) The process of co-offending. In: Smith MJ and Cornish DB (eds) Theory for practice in situational crime prevention. Devon: Willan Publishing, pp. 149-168.

Forriol Campos, M. C (2013) El terrorismo yihadista en Europa desde 1990 hasta 2012: desarrollo y aspectos organizativos. PhD thesis, Universidad Católica de Valencia "San Vicente Mártir", Spain.

Gallagher, M (2016) 'Criminalised' Islamic State Veterans-A Future Major Threat in Organised Crime Development? Perspectives on Terrorism, 10(5): 51-67.

García-Calvo C and Reinares F (2013) Procesos de radicalización violenta y terrorismo yihadista en España: ¿cuándo? ¿dónde? ¿cómo? Madrid: Real Instituto Elcano.

Jensen M (2018) Pre-Radicalization Criminal Activity of United States Extremists. START Research Brief. College Park: University of Maryland.

Jordán J and Trujillo H (2006) Favourable situations for the jihadist recruitment: The neighbourhood of Principe Alfonso (Ceuta, Spain). Athena Paper 1(3). Available at: https://www.files.ethz.ch/isn/47268/Vol1\%20No\%201\%20Art\%201.pdf

Jordán J and Wesley R (2007) The Threat of Grassroots Jihadi Networks: A Case Study from Ceuta, Spain, Terrorism Monitor 5(3). Available at: https://iamestown.org/program/the-threat-ofgrassroots-jihadi-networks-a-case-study-from-ceuta-spain/. 
Ljujic V, van Prooijen J.W and Weerman F (2017) Beyond the crime-terror nexus: socio-economic status, violent crimes and terrorism. Journal of Criminological Research, Policy and Practice 3(3): 158172.

Kruglanski A, Chen X, Dechesne M, Fishman S and Orehek E (2009) Fully Committed: Suicide Bombers' Motivation and the Quest for Personal Significance. Political Psychology 30(3): 331-357.

Makarenko T (2004) The Crime-Terror Continuum: Tracing the Interplay between Transnational Organised Crime and Terrorism. Global Crime 6(1): 129-145.

Makarenko T (2012) Europe's Crime-Terror Nexus: Links between terrorist and organised crime groups in the European Union. Brussels: European parliament.

Makarenko T and Mesquita M (2014) Categorising the crime-terror nexus in the European Union. Global Crime 15 (3-4): 259-274.

Neumann P, Basra R and Brunner C (2016) Criminal Pasts, Terrorist Futures: European Jihadists and the New Crime-Terror Nexus. London: ICSR.

Oftedal E (2015) The financing of jihadi terrorist cells in Europe. Oslo: Norwegian Defence Research Establishment (FFI).

Ranstorp M (2016) Microfinancing the Caliphate: How the Islamic State is Unlocking the Assets of European Recruits. CTC Sentine/ 9(5):11-15.

Reinares F (2014) The 2014 Madrid Train Bombings. In: Hoffman B and Reinares F (eds) The evolution of the global terrorist threat. From 9/11 to Osama bin Laden's Death. New York: Columbia University Press.

Reinares F, García-Calvo C and Vicente A (2017) Differential Association Explaining Jihadi Radicalisation in Spain: A Quantitative Study. CTC Sentinel 10(6):29-34.

Sageman M (2004) Understanding Terror Networks. Philadelphia: University of Pennsylvania Press. 
Shelley L, Picarelli J, Irby A, Hart D, Craig-Hart P, Williams P, Simon S, Abdullaev N, Stanislawski B and Covill L (2005) Methods and Motives: Exploring Links between Transnational Organized Crime \& International Terrorism. Rockville (Maryland): National Criminal Justice Reference Service (NCJRS).

Sanderson, T. M.(2004) Transnational terror and organized crime: blurring the lines. SAIS Review of International Affairs, 24(1): 49-61.

Soudijn M and Zegers B (2012) Cybercrime and virtual offender convergence settings. Trends Organ Crim 15: 111-129.

Stuart H (2017) Islamist Terrorism Analysis of Offences and Attacks in the UK (1998-2015). London: The Henry Jackson Society.

Trujillo H, Jordán J, Gutiérrez J A and González-Cabrera J (2009) Radicalization in Prisons? Field Research in 25 Spanish Prisons. Terrorism and Political Violence 21(4): 558-579.

Vidino L, Marone F and Entenmann E (2017) Fear Thy Neighbour. Radicalization and Jihadist Attacks in the West. Milan: Ledizioni LediPublishing. 